Sains Malaysiana 49(5)(2020): 1097-1106

http://dx.doi.org/10.17576/jsm-2020-4905-14

\title{
Incidental Findings of Heterakis spumosa and Chirodiscoides caviae with Pinworms in Sprague Dawley Rats
}

(Penemuan Kebetulan Heterakis spumosa dan Chirodiscoides caviae dengan Cacing Kerawit pada Tikus Sprague Dawley)

\author{
Raslan Ain-Fatin, Saulol Hamid Nur-Fazila*, Md Isa Nur-Mahiza, Abd Rahaman Yasmin, FazIL \\ MUHAMMAD-AZAM \& HAMKA NUR-KUAIN
}

\begin{abstract}
Endoparasites and ectoparasites have been one of the most common problems influencing the health condition of laboratory animals. The animals have a higher possibility of getting infected and their vague microbial status may alter the results of research studies. The objective of this study was to identify the presence of helminths and ectoparasites in Sprague Dawley (SD) rats and to determine the association between the type of helminths and ectoparasites infestation in two different conventionally-maintained animal facilities. A total of 60 SD rats were selected randomly. For helminths identification, perianal tape test and faecal floatation were used while ectoparasites were identified by fur pluck test. The data was analysed statistically by SPSS using the Pearson Chi-square test. In this study, pinworms; Syphacia muris and Aspiculuris tetraptera were identified in both Premise 1 and Premise 2. Out of 30 animals of each facility, 26 and 23 rats were found to be positive for helminths at each premise, respectively. Surprisingly, Heterakis spumosa that is commonly found in wild rats were identified at Premise 2. Additionally, 22 out of 30 SD rats at Premise 2 were infested heavily with Chirodiscoides caviae mites which are common in guinea pigs. The high burden of $\mathrm{C}$. caviae infestation was most likely due to cross-contamination during transportation. Statistically, there was an association between the type of helminths and ectoparasites infestation in SD rats at different animal facilities ( $p$-value $=0.009)$. In conclusion, different practise of conventionally-maintained animal facilities influence the evidence of uncommon parasites infestation without affecting the presence of common pinworms in laboratory rats.
\end{abstract}

Keywords: Chirodiscoides caviae; ectoparasites; helminths; Heterakis spumosa; laboratory rats

ABSTRAK

Endoparasit dan ektoparasit telah menjadi salah satu masalah umum yang mempengaruhi keadaan kesihatan haiwan makmal. Haiwan-haiwan ini mempunyai kemungkinan yang tinggi untuk mendapat jangkitan dan status mikrob mereka yang tidak jelas boleh mengubah hasil kajian penyelidikan. Objektif kajian ini adalah untuk mengenal pasti kehadiran helmint dan ektoparasit pada tikus Sprague-Dawley (SD) dan untuk menentukan hubungan antara jenis helminth dan ektoparasit di dua fasiliti haiwan makmal yang dikendalikan secara konvensional. Sejumlah 60 tikus SD telah dipilih secara rawak. Untuk mengenal pasti helmint, ujian pita perianal dan pengapungan tinja dijalankan sementara ektoparasit dikenal pasti dengan ujian cabutan bulu. Data dianalisis secara statistik oleh SPSS menggunakan ujian Pearson Chi-square. Dalam kajian ini, cacing kerawit; Syphacia muris dan Aspiculuris tetraptera telah dikenal pasti dalam kedua-dua Premis 1 dan Premis 2. Daripada 30 haiwan di setiap kemudahan, 26 dan 23 tikus didapati positif untuk helmint. Yang mengejutkan. Heterakis spumosa yang kebiasaannya dijumpai pada tikus liar dan jarang dilaporkan dalam tikus makmal juga telah dikenal pasti di Premis 2. Selain itu, 22 daripada 30 tikus SD di Premis 2 juga mempunyai infestasi tinggi oleh Chirodiscoides caviae hama yang kebiasaannya dijumpai dalam tikus belanda. Beban tinggi C. caviae berkemungkinan besar disebabkan oleh jangkitan semasa pengangkutan. Secara statistik, terdapat hubungan antara jenis helmint dan serangan ektoparasit pada tikus SD di fasiliti haiwan makmal yang berbeza (p-value =0.009). Sebagai kesimpulan, pengurusan yang berbeza antara fasiliti haiwan makmal yang dikendalikan secara konvensional akan mempengaruhi serangan parasit yang jarang berlaku tanpa menjejaskan kehadiran cacing kerawit dalam tikus makmal.

Kata kunci: Chirodiscoides caviae; ektoparasit; helmint; Heterakis spumosa; tikus makmal

\section{INTRODUCTION}

Laboratory rats are rodents that belong to the family Muridae and are the members of genus Rattus (Cafiero et al. 2016). For scientific research, Rattus norvegicus is the most frequent laboratory animal used other than the mice (Canzian 1997) as they are less expensive, easy to 
breed and easy to restraint upon handling. They contribute to our understanding of physiology, diseases, behaviour, and genome mapping. The physiology of the rat is also similar in human conditions and the rat has become a standardized physiological and toxicological model, particularly in the pharmaceutical industry (Iannaccone \& Jacob 2009).

Conventional animal facilities refer to the standard housing facility for laboratory rodents with barrier and containment systems with no other added level of control (Hessler \& Lehner 2011). The term 'conventional' can also be defined as the facility where the animals are kept in. The animals are housed without special precautions to inhibit entry of infectious agents thus have a higher possibility of getting infected as compared to barrier-housed animals (Nicklas 2004). Conventional laboratory animals are defined as animals that do not undergo routine health monitoring, originate from uncontrolled colonies and are not treated if found to be infected (Otto \& Franklin 2005). The status of microbial infection of these animals is vague as they are kept in facilities without specialized sanitary barriers (Andersen et al. 2015). According to the Canadian Council on Animal Care (1984), animals intended for use of research in various fields such as oncology, immunology, and biomedicine require the animals to be microbiologically 'clean' thus, defining them as free of pathogens such as viral and bacterial agents. It is imperative to identify the microbiological status of the animals used for experimental research to be published and also to reduce cross-contamination between different areas (Baker et al. 1979). Cross-contamination may lead to outbreaks of disease in different colonies as reported by Carty (2008) who showed that cross-contamination of several viruses occurred due to the contamination of biological material.

Helminths are parasitic worms comprised of tapeworm, pinworm, and trichinosis that potentially cause disease and illness to the host. They can be transmitted through contaminated food, water, soil, or fomites. It is common for laboratory rats either housed semi-openly or conventionally to harbour intestinal helminths (Eaton 1972). Other than helminths infection, they can also be infested with ectoparasites that live outside the body of the host such as lice, mites, and fleas. Heavy external and internal parasitic infestation can lead to loss of research effort, time, and money if appropriate preventive measures are not practised (Griffiths 1971). Preventative measures refer to strict sanitary barriers, separating different species and sanitary monitoring in the animal facilities targeting for high-quality laboratory animals intended for any research purpose (Bicalho et al. 2007). Mild infestations are difficult to be detected but will appear to compromise the health of the animal in stressful conditions. In a study by Plachý et al. (2016), it was shown that pinworm infestation affects the nutrient digestibility in rats especially for crude fibre and mineral ash. Pinworms have also been shown to affect the growth of rats where infected rats were less likely to grow faster or gain weight as compared to uninfected rats (Wagner 1988).

The current reduction in parasite prevalence and incidence are mostly due to better improvements in hygiene, nutrition, housing systems, environmental control, disease surveillance, treatment, and quality of the animals. Therefore, it is rare to find laboratory rats parasitized with more than a very narrow spectrum of pathogens in modern animal facilities (Baker 2007). The Canadian Council on Animal Care (1984) mentioned that the nature of diseases in laboratory rats had a marked change through selection, improved husbandry, and effective health assessment program. It is rare to find major health problems in today's rat colony. As recommended by Federation for Laboratory Animal Science Associations (FELASA) and reported by Nicklas et al. (2002), animal facilities should integrate a proper laboratory animal health monitoring (HM) program to ensure the quality of the place by subjecting the animals to frequent health monitoring and diagnostic procedures. Furthermore, in current times, animal facilities for laboratory rats rely heavily on biosecurity management and usage of various levels of barrier maintenance to separate animals from possible sources of infection in order to maintain the status of microbiological control.

Nevertheless, a high burden of parasitic infestation influences the outcome of the research study and may appear clinically and subclinically healthy animals. The subclinical healthy animals may harbour pathogenic organisms without showing any clinical signs but they are susceptible to diseases during a stressful episode. Subsequently, these parasites may influence the data collection and interfere with the outcome of the research study and validation of the data, with the addition of possible unreliable experimental results (Griffiths 1971). The researchers need to obtain laboratory rats from reliable sources to ensure the good quality of laboratory animals used for their research works. Thus, this research was carried out with the objectives of studying the presence of helminths and ectoparasites in Sprague Dawley (SD) rats and to determine the association between the type of helminths and ectoparasites infestation in two different conventionally-maintained animal facilities. This study can provide the health status and parasitic levels of the laboratory mice in different management factors that may reflect management practised in different facilities.

\section{MATERIALS AND METHODS}

Several tests were carried out for identification of helminths and ectoparasites in Sprague Dawley (SD) rats where this study took place at Veterinary Parasitology Laboratory, Faculty of Veterinary Medicine, Universiti 
Putra Malaysia. For identification of helminths, perianal tape test (Owen 1992) and faecal floatation (Pritchett 2007) were done while fur pluck test was conducted for ectoparasites identification (Parkinson et al. 2011). A total of sixty (60) SD rats were randomly selected where thirty (30) SD rats were chosen for each premise. Faeces were collected in the morning at Premise 1 and late afternoon at Premise 2 due to limited time and time difference in visiting hours of each animal facility. Identification of helminths and ectoparasites were done based on observation and classification of their distinct characteristics under examination using a compound microscope. This study has been approved by UPM Institutional Animal Care and Usage Committee (IACUC) with an approval code of UPM/IACUC/AUP-U048/2018.

\section{LOCATION OF STUDY}

For ethical reasons, the name of both premises are not disclosed and are only identified as Premise 1 and 2 . Premise 1 is managed as a closed environment facility equipped with proper biosecurity practised such as airlocks for staff, dedicated laboratory clothing, and unidirectional traffic flow. It is also located in isolation from any other buildings. Premise 2 is managed as an open environment facility with open windows and located close to shopping lot units. Premise 2 does not practice any biosecurity measures.

\section{PERIANAL TAPE TEST}

The rats were restrained by the tail with the hind legs lifted from the ground. Then, a clear cellophane tape about $5 \mathrm{~cm}$ in length was used for each animal for the perianal tape impression. The tape was grasped with both thumb and index finger at the end part of the tape while the middle part of the tape was applied firmly to the perianal region of the rat. This was applied a few times five (5) times to ensure the possible parasites at the region can stick to the tape. Lastly, the tape was placed on a clean glass slide for microscopic examination under $100 \times$ and $400 \times$ magnification magnification (Baker 2007; Owen 1992).

\section{FAECAL FLOATATION}

Faecal floatation technique was carried out to look for helminth ova and larval stages as well as to detect for coccidian oocysts. Fresh faecal samples from individual rats were collected. The faeces weighing about $1 \mathrm{~g}$ were mixed with $40 \mathrm{~mL}$ of sodium nitrate solution with a specific gravity of 1.3 . The mixture was then filtered using a sieve to remove any large particles before pouring it in a vial until a meniscus was formed at the top of the vial. A coverslip was placed on top of the vial before it was left for $20 \mathrm{~min}$. After that, the coverslip was lifted up gently and it was transferred to a glass slide for examination under $100 \times$ and $400 \times$ magnification microscope (Baker 2007; Owen 1992).

\section{FUR PLUCK EXAMINATION}

Fur pluck examination was used for detection of ectoparasites such as Myobia sp. and Polyplax sp. First, the body grab technique was used to restraint the rat. Then, tufts of fur were grasped using hemostats and gently plucked from the areas of the rat's scapular, ventral cervical region, axillary, inguinal, and dorsal rump. After that, the fur was placed on the glass slide with a drop of mineral oil before covering it with a coverslip. Lastly, the microscope slide was examined by using a light microscope at 100x and 400x magnification (Ballweber \& Harkness 2007; Owen 1992).

\section{STATISTICAL ANALYSIS}

Statistical analysis was carried out using the software Statistical Packages for the Social Sciences 25.0 (SPSS). The association between the type of helminths and ectoparasites infestation in SD rats with the different animal facilities were analyzed using Pearson's ChiSquare method and it was considered significant when $\mathrm{P}<0.05$. Pearson's Chi-Square method was used because the data was not normally distributed and the categorical variables are more than one.

\section{RESULTS}

Our study showed that the helminths identified from both animal facilities were Syphacia muris, Aspiculuris tetraptera and Heterakis spumosa based on the distinct characteristics on the anterior and posterior anatomical structure as well as the ova characteristic.

Syphacia muris is the most common pinworm seen in laboratory rats. The ova were observed with measurements of $79.18 \mu \mathrm{m}$ long and $30.14 \mu \mathrm{m}$ wide at $400 \times$ magnification (Figure 1). The ova can be identified as vermiform in shape, slightly flattened on one side, and measures of $72-82 \mu$ long by $25-36 \mu$ wide. Secondly, A. tetraptera is the second most common pinworm in laboratory mice but it was less common in laboratory rats. The ova can be identified by its symmetrically ellipsoidal shape and the measurements are $70-98 \mu$ long and $29-50 \mu$ wide. Figure 2 shows that Aspiculuris tetraptera ova was measured with $95.27 \mu \mathrm{m}$ long by $41.19 \mu \mathrm{m}$ wide at $400 \times$ magnification. Thirdly, H. spumosa is a common roundworm in wild rats, but uncommon to be found in laboratory rats. The ova are characterized by a very thick mamillated shell and has measurements of $55-60 \mu$ long and $40-55 \mu$ wide. The ova were found to be measured with $57.32 \mu \mathrm{m}$ long and $42.39 \mu \mathrm{m}$ wide at $400 \times$ magnification (Figure 3). 

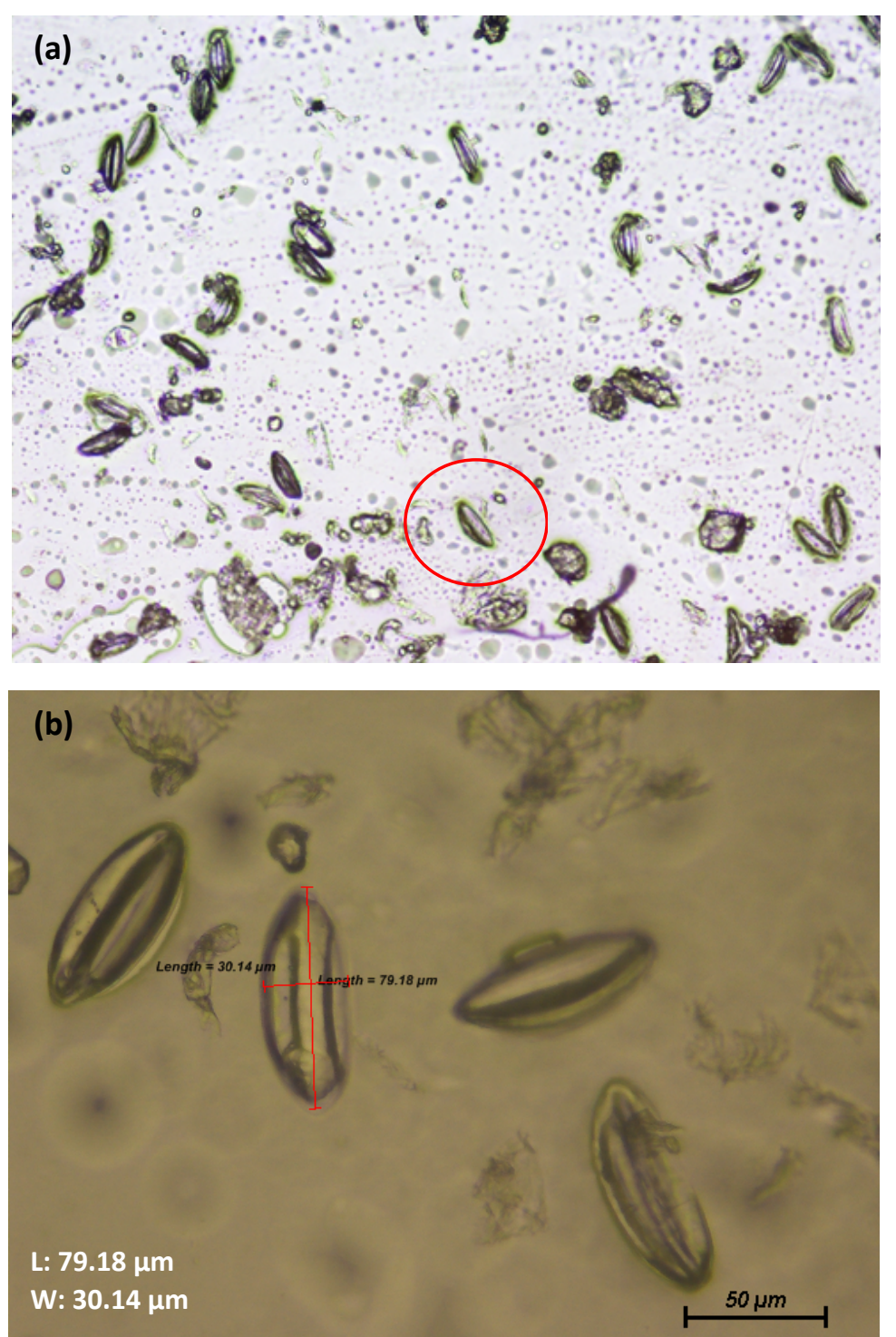

FIGURE 1. Presence of Syphacia muris, (A) Syphacia muris ova at $100 \times$ magnification, (B) Syphacia ova showed vermiform shape with measurements of 79.18 $\mu \mathrm{m}$ long by $30.14 \mu \mathrm{m}$ wide at $400 \times$ magnification

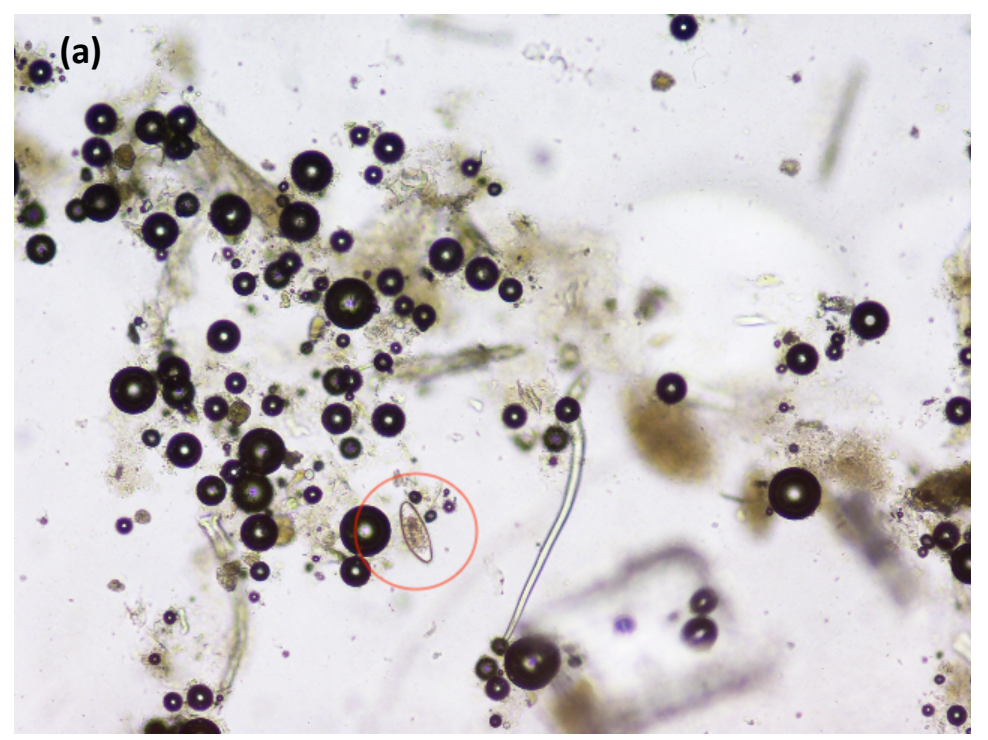




\section{(b)}

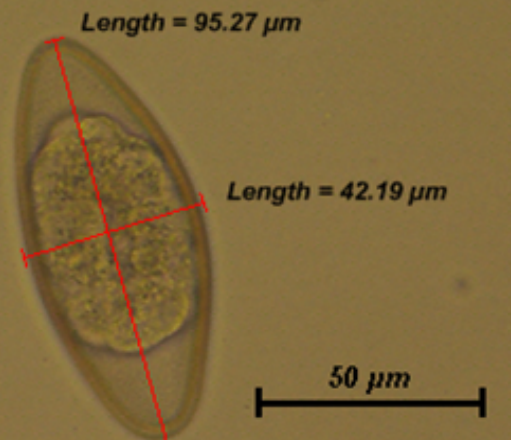

L: $95.27 \mu \mathrm{m}$

$\mathrm{W}: 30.14 \mu \mathrm{m}$

FIGURE 2. Presence of Aspiculuris tetraptera, (A) Aspiculuris tetraptera ova (circle) at 100× magnification, and (B) Ova of Aspiculuris tetraptera with ellipsoidal in shape measuring 95.27 $\mu \mathrm{m}$ long by $41.19 \mu \mathrm{m}$ wide at $400 \times$ magnification
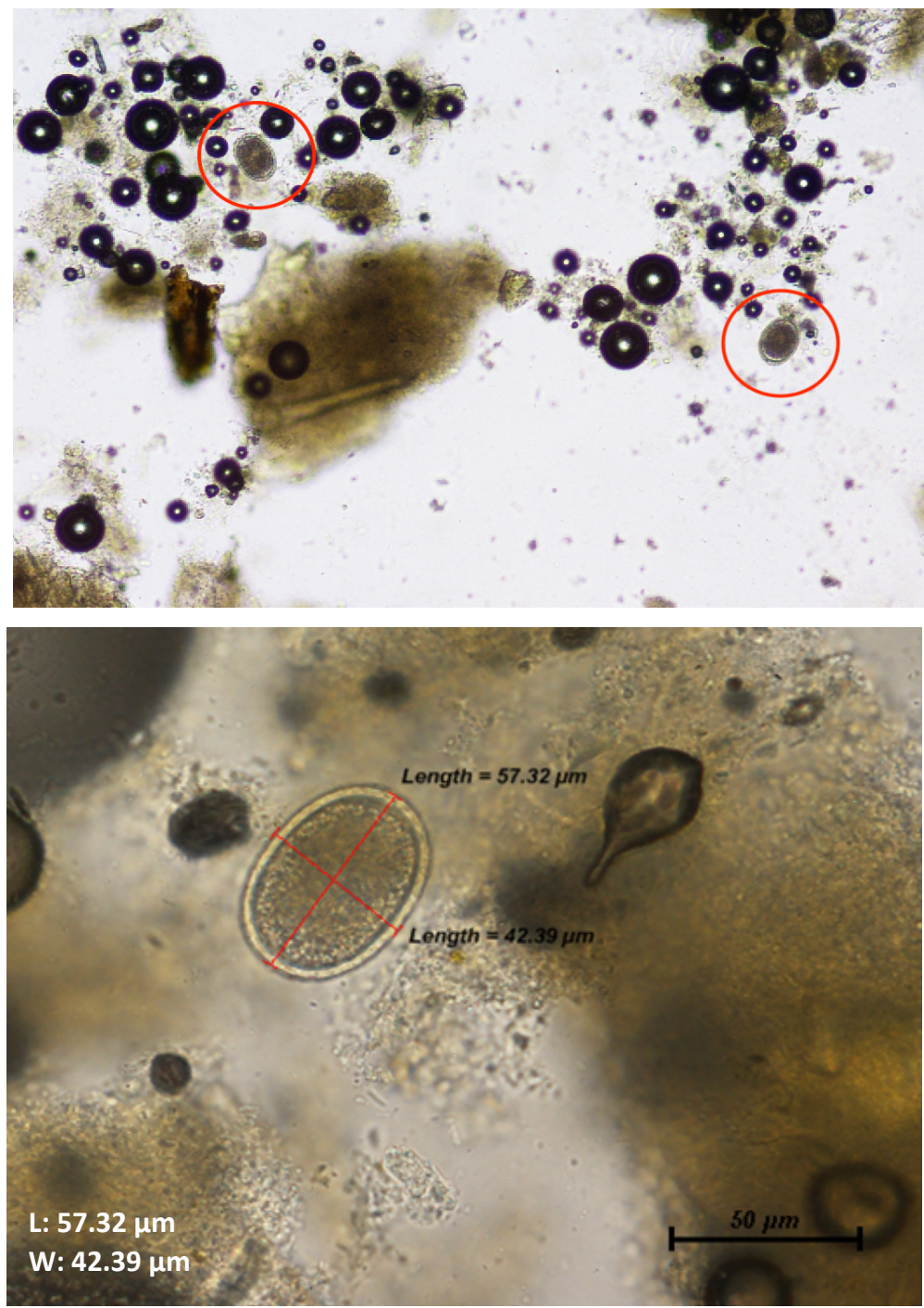

FIGURE 3. Presence of Heterakis spumosa, (A) Evidence of Heterakis spumosa ova at 100× magnification, and (B) Heterakis spumosa ova is oval shape surrounded by a thick mamillated shell with measurements of $57.32 \mu \mathrm{m}$ long and $42.39 \mu \mathrm{m}$ wide at $400 \times$ magnification 


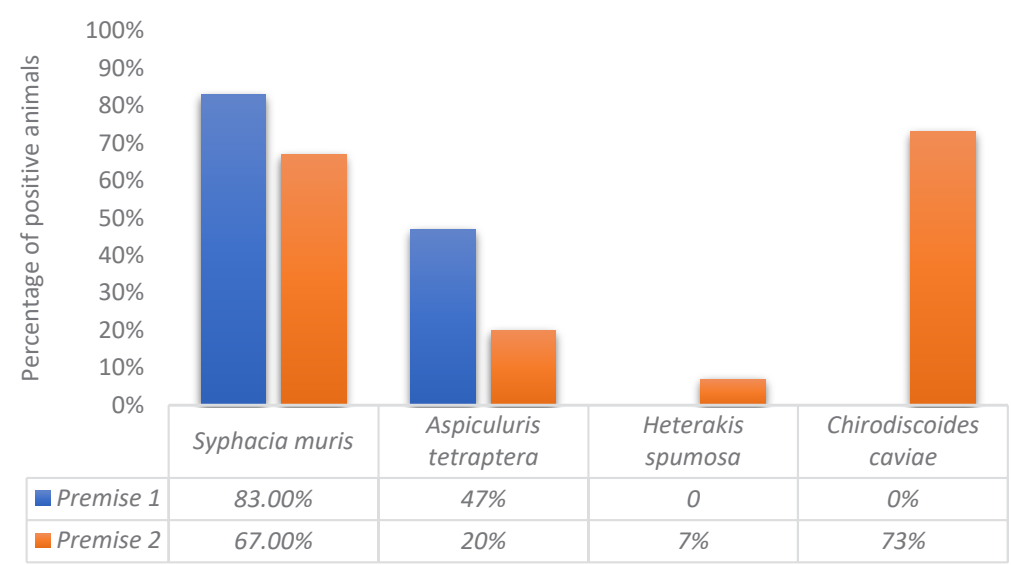

FIGURE 4. Comparison of Sprague Dawley rats infected by Syphacia muris, Aspiculuris tetraptera, Heterakis spumosa and Chirodiscoides caviae for Premise 1 and Premise 2

A bar chart in Figure 4 illustrated the relationship between the types of parasites between the two animal facilities. It showed $83 \%$ of rats at Premise 1 were found to be shedding $S$. muris ova while at Premise $2,67 \%$ of rats were affected with $S$. muris. For A. tetraptera, $47 \%$ of the SD rats at Premise 1 were infected while $20 \%$ of them were found to be infected from Premise 2. This shows that $S$. muris and A. tetraptera infection were higher at Premise 1 as compared to Premise 2 although there is no significant difference between the two premises. The high infection of $A$. tetraptera in Premise 1 could occur due to a varying frequency of bedding change between the two premises as they are done subjectively ranging from twice weekly, once weekly and once in two weeks. This bar chart illustrated that $H$. spumosa was presented in Premise 2 where this infection is rare in laboratory rats. For ectoparasites, there is a significant difference between fur mites that were only found at Premise 2 but none seen at Premise 1.

(a)

(b)
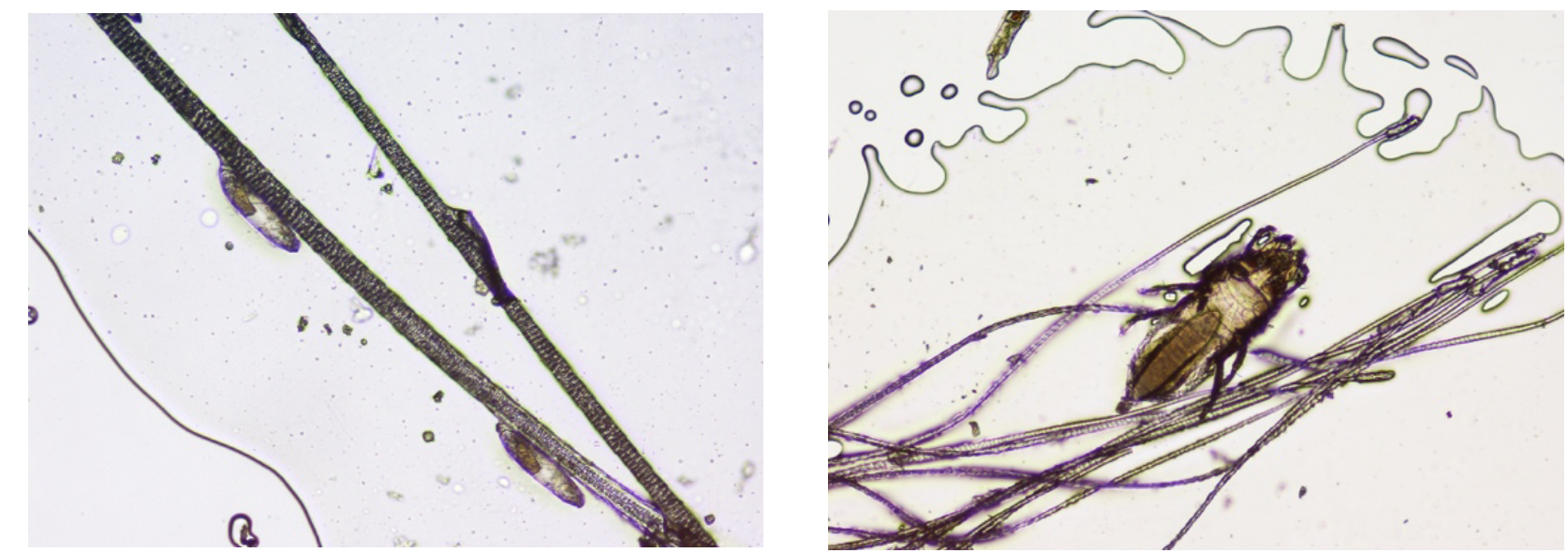

FIGURE 5. Ectoparasite found in Premise 2, (A) Presence of Chirodiscoides caviae eggs on the hair shaft under 100× magnification, and (B) Evidence of a female adult mite measuring $379.66 \mu \mathrm{m}$ long by $115.82 \mu \mathrm{m}$ wide at $400 \times$ magnification

Although none of the SD rats was found to be positive for any ectoparasites in Premise 1, surprisingly, 22 out of 30 rats ( $73 \%$ positive) were found to be heavily infested with C. caviae mites at Premise 2. Chirodiscoides caviae is a fur mite commonly found in guinea pigs but is now rarely reported in guinea pigs due to improvements in laboratory animal husbandry. It has long slender eggs that are laid halfway up the hair shafts as seen in Figure 5. The adult females have measurements of $502 \mu \mathrm{m}$ to $528 \mu \mathrm{m}$ long while the males are smaller measuring 
with $350 \mu \mathrm{m}$ to $376 \mu \mathrm{m}$ long. The mean width of the $C$. caviae has been described as $115.4 \mu \mathrm{m}$ for male mites and $139 \mu \mathrm{m}$ for female mites. However, a female mite shown in Figure 5 was measured at $379.66 \mu \mathrm{m}$ long by $115.82 \mu \mathrm{m}$ wide under 100x magnification is suggested to be juvenile as it does not reach an adult size yet. The nymph stage can be characterized by a series of scales running along the dorsal surface. The female mite was characterized by heavily chitinized and long first two pairs of legs adapted for wrapping around the hair shaft, whereas the third and fourth legs are unspecialized.

The cross-infection of $H$. spumosa and presence of ectoparasites in Premise 2 could occur due to the condition where the animals are bred and the management of the animal facilities. These animals are bred in openwindowed rooms as seen in Figure 6 possibly exposing them to wild rats. In contrast, the rats kept in Premise 1 are housed completely indoors with no access to the outside environment as seen in Figure 6. Although both premises are used to house laboratory animals, the biosecurity measures and management practises for both premises are different from one another. Statistical analysis by Pearson's Chi-Square method proved that there was an association between the type of helminths and ectoparasites infestation in Sprague-Dawley rats with the different management of animal facility since the value obtained was $\mathrm{P}<0.05$ which was significant.

From this study, it has been found that there is higher infection of Syphacia muris observed in SD rats at Premise 1 as compared to animals housed at Premise 2 despite the fact that Premise 2 had a higher stocking density of animals accounting for 15 to 20 rats per cage as compared to Premise 1 ( $<10$ rats). Despite high stocking density being linked to reduced circulating antibodies (Vessey 1964) and reduced resistance to infection in mice (Brayton \& Brain 1974; Peterson et al. 1991), we hypothesized that stocking density may not play a role in parasitic burden. This finding is also supported by a recent study aimed to characterize the effect housing status of mice on the isolation of $A$. tetraptera eggs by comparing singly-house, paired and grouped mice (Goodroe et al. 2016). Housing status was found not to be an important factor regarding the number of eggs isolated from the mice over time. It was instead suspected to be due to natural variation in infection. Therefore, the results of our study may be inconclusive and would benefit greatly from replication of sampling from the animal facilities to increase the number of rats studied in order to prove that stocking density influence the parasitic burden.

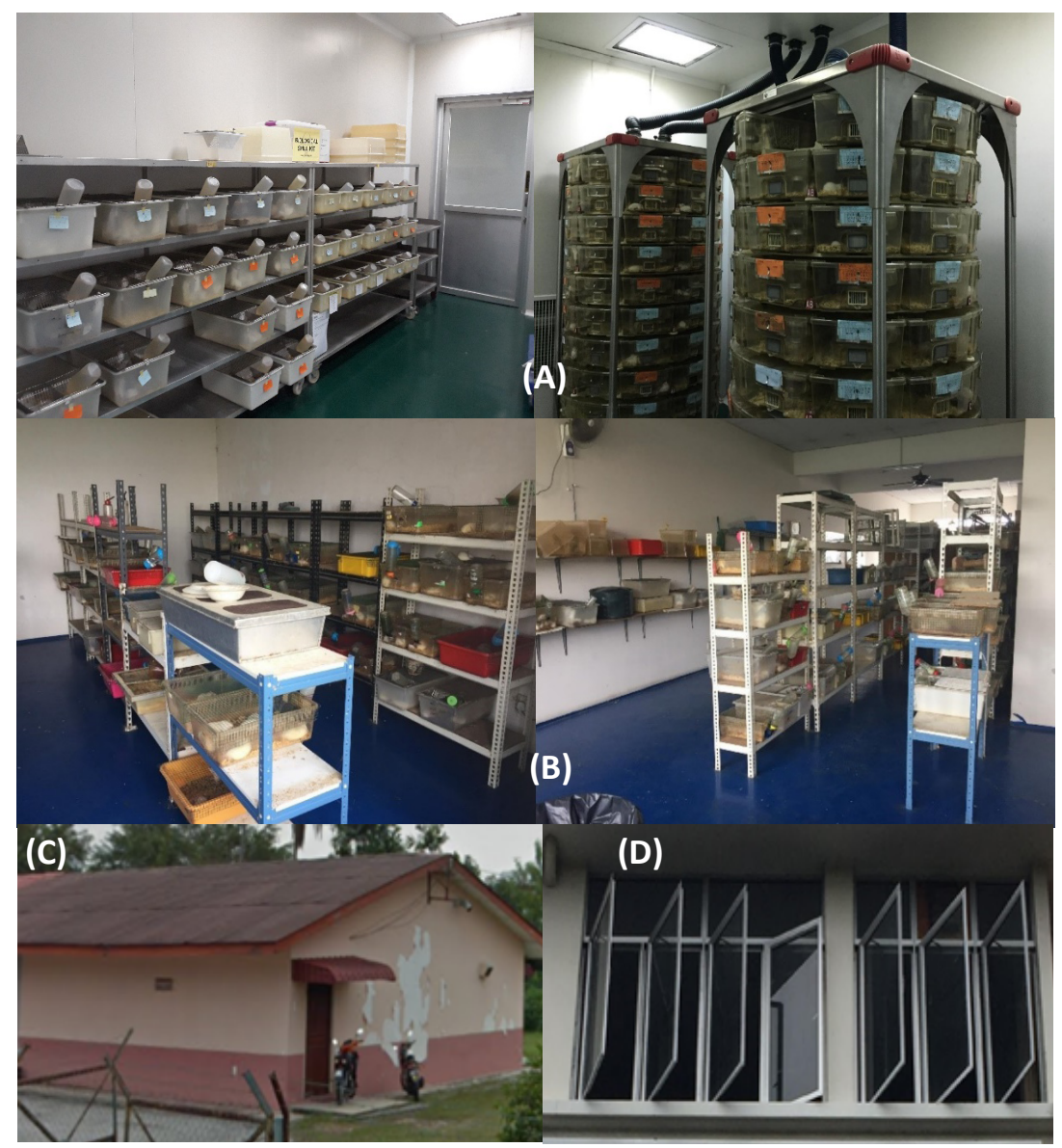

FIGURE 6. Layout of breeding unit and facility at Premise 1 and Premise 2 (A) Breeding area with separate cages for breeder pairs, juvenile and adults at Premise 1, (B) Unseparated breeding area at Premise 2, (C) Isolated building with closed environment of animal facility at Premise 1, and (D) Shop lot unit with open-windowed animal facility at Premise 2 
During the collection of samples, the perianal tape test method was used to detect the ova of $S$. muris because the worms release their eggs at the perianal region. Based on Baker (2007), the perianal tape test method is best performed in the afternoon, because perianal egg counts are higher during this time. A study by D'Silva (1982) showed that the female worms may release up to 4000 eggs per day on the host's perianal region where $23 \%$ of eggs are released at 8 in the morning, $12 \%$ at 10 am and peak egg release of $32 \%$ at 12 noon. Egg release was shown to drop to less than $8 \%$ during late afternoon from $2 \mathrm{pm}$ until $6 \mathrm{pm}$. It is influenced by the nocturnal behaviour of the rat and the lighting regime in the environment where rats feed and defecate during night time thus female worms release eggs when rats are at rest to avoid egg loss through faeces at night. However, there is a discrepancy in this study as the faeces samples were collected from afternoon to evening at Premise 1 while sampling was done in the early morning at Premise 2. This was due to the limited time given and time difference in visiting hours of each animal facility. Thus, these factors could be the reason to contribute to a higher burden of $S$. muris observed in rats at Premise 1 although Premise 2 had a higher stocking density. The results are inconclusive but showed the possibility that the time of sampling influence the parasitic load of $S$. muris as mentioned previously (Baker 2007; D’Silva 1982). Thus, these factors should be standardized to ensure the validation of the data.

Other than that, our results showed that SD rats infected with $A$. tetraptera at Premise 1 were higher than those in Premise 2 rats although there was no significant difference found. Interview session with the working personnel of both premises showed that the change of bedding was done subjectively if the personnel considered that the cages were dirty based on observation. Thus, we speculated that the varying frequency of bedding change by the personnel in charge between these two premises could cause variation of $A$. tetraptera load between Premise 1 and Premise 2. This could be supported by a statement from Baker (2007) who mentioned that unembryonated eggs are passed in the faeces where the eggs embryonate in the environment and become infective in $5-8$ days. Thus, frequent change of bedding is effective in controlling this parasite.

Heterakis spumosa is a roundworm that is commonly found in wild rats but rarely found in laboratory animals (Owen 1992). However, 2 out of 30 of the rats at Premise 2 were infected while there was no infestation in Premise 1 rats. The location of the premises could play an important role to contrast the levels of parasitic infestation. Premise 2 is located neighbouring to shop lots with a higher plausibility of wild rats roaming nearby. The rats were placed in rooms with windows widely open during the day thus exposing them to the outside environment. Source of food for the rats are kept inside the same premise thus there is a possibility of attracting wild rats to enter the premise through the open window. This may explain the infection of $H$. spumosa occurring at the premise. This differs completely from Premise 1 that is located in isolation from other buildings with proper biosecurity practised such as airlocks for staffs, dedicated lab clothing and footwear, and unidirectional traffic flow inside the laboratory animal facility. This reduces the chance of wild rats to enter the premise which may contribute to the absence of $H$. spumosa infection at Premise 1. Intriguingly, H. spumosa has not been reported from laboratory animal colonies for many years based on Baker (2007). Although it is a nonpathogenic nematode, this reflects the general hygiene of the premise as wild rats can promote unwanted diseases that can be transmitted to the laboratory rats as well as the personnel in the facility.

Chirodiscoides caviae is a common fur mite of guinea pigs (Sundar et al. 2017). In this case, 22 out of 30 rats at Premise 2 were found to be infested with the mite indicating that there was cross-contamination of SD rats with guinea pigs. Upon interviewing with the facility manager, it was mentioned that there was no history of bringing in guinea pigs into the premise. However, the animals had been brought from a breeder and they had shared the same transportation with guinea pigs breeder a few weeks ago. Hence, it is the most possible route for the occurrence of cross-contamination during the transportation process which may reflect the fur mite manifestation in the rats at Premise 2. Furthermore, the premise has poor ventilation and higher stocking density in individual cages which could contribute to the spread of the mites causing a high infestation in $73 \%$ of the rats.

Despite both of the location study being maintained as conventional animal facilities and serve as a source of laboratory animals for research purposes, it showed a jarring difference in parasitic burden between the two premises. Therefore, ensuring the reliability of the source when obtaining laboratory rats to be used as an animal model for any research study is crucial as the animals may be unmonitored and presented with various underlying diseases that may alter the outcome of any research studies. Striving for sources with 'microbiologically' clean animals should be the utmost importance when obtaining the animal models for research.

\section{CONCLUSION}

To sum up, helminths that were identified in the SpragueDawley rats were Syphacia muris, Aspiculuris tetraptera and Heterakis spumosa while Chirodiscoides caviae mites were the only ectoparasites detected. Our data also showed an association between the type of helminths and ectoparasites infestation in Sprague-Dawley rats from different managements of conventionally-maintained animal facilities. In addition, there is an opportunity to further improve the study by standardizing the time 
taken for sampling and carrying out higher sensitivity parasitological method like PCR testing for parasites characterisation to provide better insight on the parasitic identification.

\section{ACKNOWLEDGEMENTS}

This work was supported by the Project Grant Putra (UPM/700-2/1/GP-IPM/2017/9526900). The authors would like to thank UPM as research grant provider and also to all the staff of Animal Resource Unit and Veterinary Parasitology Laboratory, Faculty of Veterinary Medicine, UPM who helped in the project particularly Mrs. Maizatul, Mr. Rashid, Mr. Zainuddin, Mr. Kamarzaman, Mr. Aizat and Mr. Ismail Shaari.

\section{REFERENCES}

Andersen, M.L., D’Almeida, V., Ko, G.M., Martins, P.J.F. \& Tufik, S. 2015. The health of laboratory animals. In Rodent Model as Tools in Ethical Biomedical Research, edited by Andersen, M.L. \& Tufik S. Switzerland: Springer Nature Publishing. pp. 53-60.

Baker, D.G. 2007. Parasites of rats and mice. In Flynn's Parasites of Laboratory Animals. 2nd ed. Ames (IA): Blackwell Publishing. pp. 1-13.

Baker, H.J., Lindsey, J.R. \& Weisbroth, S.H. 1979. Housing to control research variables. In The Laboratory Rat, edited by Baker, H.J., Lindsey, J.R. \& Weisbroth, S.H. Toronto, Ontario: Academic Press. pp. 169-192.

Ballweber, L.R. \& Harkness, J.E. 2007. Parasites of guinea pigs. In Flynn's Parasites of Laboratory Animals, edited by Baker, D.G. 2nd ed. Ames (IA): Blackwell Publishing. pp. 1-13.

Besch-williford, C. \& Franklin, C. 2007. Clinical parasitology of laboratory rodents \& rabbits. Presented at the 2007 FELASA - ICLAS meeting. pp. 8-12.

Bicalho, K.A., Araújo, F.T.M., Rocha, R.S. \& Carvalho, O.S. 2007. Sanitary profile in mice and rat colonies in laboratory animal houses in Minas Gerais: I - endo and ecto-parasites. Arquivo Brasileiro de Medicina Veterinária e Zootecnia 59(6): 1478-1484.

Brayton, A.R. \& Brain, P.F. 1974. Proceedings: Studies on the effects of differential housing on some measures of disease resistance in male and female laboratory mice. The Journal of Endocrinology 61(2): 48-49.

Cafiero, M.A., Raele, D.A., Mancini, G. \& Galante, D. 2016. Dermatitis by tropical rat mite, Ornithonyssus bacoti (M. esostigmata, M. acronyssidae) in Italian city-dwellers: A diagnostic challenge. Journal of the European Academy of Dermatology and Venereology 30(7): 1231-1233.

Canadian Council on Animal Care. 1984. In Guide to the Care and Use of Experimental Animals - Volume 2. Canadian Council on Animal Care, Ottawa Ont. pp. 1-31. https://www. ccac.ca/Documents/Standards/Guidelines/Vol2/rats.pdf.

Canzian, F. 1997. Phylogenetics of the laboratory rat Rattus norvegicus. Genome Research 7(3): 262-267.

Carty, A.J. 2008. Opportunistic infections of mice and rats: Jacoby and Lindsey revisited. ILAR Journal 49(3): 272276.
D'Silva, J. 1982. The transmission of Syphacia muris (nematoda; oxyuroiuea) in the laboratory rat. Doctor of Philosophy Theses. University of London (Unpublished).

Eaton, G.J. 1972. Intestinal helminths in inbred strains of mice. Laboratory Animal Science 22(6): 850-853.

Griffiths, H.J. 1971. Some common parasites of small laboratory animals. Laboratory Animals 5(1): 123-135.

Goodroe, A.E., Baxter, V.K. \& Watson, J. 2016. Guidance regarding sample collection and refinement of fecal flotation exam for the isolation of Aspiculuris tetraptera. Journal of the American Association for Laboratory Animal Science 55(5): 541-547.

Hessler, J. \& Lehner, N. 2011. Introduction. In Planning and Designing Research Animal Facilities, edited by Hessler, J. \& Lehner, N. Massachusetts: Academic Press. pp. 3-5.

Iannaccone, P.M. \& Jacob, H.J. 2009. Rats!. Disease Models \& Mechanisms 2(6): 206-210.

Nicklas, W. 2004. Infections in laboratory animals: Importance and control. In The Welfare of Laboratory Animals, edited by Kaliste, E. Springer Science \& Business Media. pp. 23-35.

Nicklas, W., Baneux, P., Boot, R., Decelle, T., Deeny, A.A., Fumanelli, M. \& Illgen-Wilcke, B. 2002. F.E.L.A.S.A. Recommendations for the health monitoring of rodent and rabbit colonies in breeding and experimental units. Laboratory Animals 36(1): 20-42.

Otto, G. \& Franklin, C.L. 2005. Medical management and diagnostic approaches. In The Laboratory Rat, edited by Suckow, M.A., Weisbroth, S.H. \& Franklin C.L. Elsevier Academic Press. pp. 548-563.

Owen, G.D. 1992. Parasites of laboratory animals. In Laboratory Animal Handbooks No. 12. SAGE Publications Ltd. pp. 30-35.

Peterson, P.K., Chao, C.C., Molitor, T., Murtaugh, M., Strgar, F. \& Sharp, B.M. 1991. Stress and pathogenesis of infectious disease. Reviews of Infectious Diseases 13(4): 710-720.

Plachý, V., Litvinec, A., Langrová, I., Horáková, B., Sloup, V., Jankovská, I. \& Borkovcová, M. 2016. The effect of Syphacia muris on nutrient digestibility in laboratory rats. Laboratory Animals 50(1): 39-44.

Pritchett, K.R. 2007. Helminth parasites of laboratory mice. In The Mouse in Biomedical Research. Massachusetts: Academic Press. pp. 551-564.

Sundar, S.B., Harikrishnan, T.J., Latha, B.R., Gomathinayagam, S., Srinivasan, M.R. \& Ramesh, S. 2017. Incidence of fur mite infestation in laboratory rodents. Journal of Parasitic Diseases 41(2): 383-386.

Vessey, S.H. 1964. Effects of grouping on levels of circulating antibodies in mice. Proceedings of the Society for Experimental Biology and Medicine 115(1): 252-255.

Wagner, M. 1988. The effect of infection with the pinworm (Syphacia muris) on rat growth. Laboratory Animal Science 38(4): 476-478.

Raslan Ain-Fatin, Saulol Hamid Nur-Fazila*, Md Isa NurMahiza, Fazil Muhammad-Azam \& Hamka Nur-Kuain Department of Veterinary Pathology and Microbiology Faculty of Veterinary Medicine

Universiti Putra Malaysia

43400 UPM Serdang, Selangor Darul Ehsan Malaysia 
Abd Rahaman Yasmin

Department of Veterinary Laboratory Diagnostics

Faculty of Veterinary Medicine

Universiti Putra Malaysia

43400 UPM Serdang, Selangor Darul Ehsan

Malaysia
*Corresponding author; email: nurfazila@upm.edu.my

Received: 28 March 2019

Accepted: 15 January 2020 